University of Nebraska - Lincoln

DigitalCommons@University of Nebraska - Lincoln

Faculty Papers and Publications in Animal

Science

Animal Science Department

November 2002

\title{
Effects of urea, isolated soybean protein and blood meal on growing steers fed a corn-based diet
}

\author{
W. F. Knaus \\ University of Agricultural Sciences, Gregor Mendel-Strasse 33, A-1180 Vienna, Austria \\ Donald $\mathrm{H}$. Beerman \\ University of Nebraska-Lincoln, Beermann@iastate.edu
}

L. O. Tedeschi

Cornell University

M. Czajkowski

Cornell University

D. G. Fox

Cornell University

See next page for additional authors

Follow this and additional works at: https://digitalcommons.unl.edu/animalscifacpub

Part of the Animal Sciences Commons

Knaus, W. F.; Beerman, Donald H.; Tedeschi, L. O.; Czajkowski, M.; Fox, D. G.; and Russell, J. B., "Effects of urea, isolated soybean protein and blood meal on growing steers fed a corn-based diet" (2002). Faculty Papers and Publications in Animal Science. 111.

https://digitalcommons.unl.edu/animalscifacpub/111

This Article is brought to you for free and open access by the Animal Science Department at DigitalCommons@University of Nebraska - Lincoln. It has been accepted for inclusion in Faculty Papers and Publications in Animal Science by an authorized administrator of DigitalCommons@University of Nebraska - Lincoln. 


\section{Authors}

W. F. Knaus, Donald H. Beerman, L. O. Tedeschi, M. Czajkowski, D. G. Fox, and J. B. Russell 


\title{
Effects of urea, isolated soybean protein and blood meal on growing steers fed a corn-based diet
}

\author{
W.F. Knaus ${ }^{\mathrm{a}, *}$, D.H. Beermann ${ }^{\mathrm{b}}$, L.O. Tedeschi ${ }^{\mathrm{c}}$, \\ M. Czajkowski ${ }^{\mathrm{c}}$, D.G. Fox ${ }^{\mathrm{c}}$, J.B. Russell ${ }^{\mathrm{d}, \mathrm{e}}$ \\ a Department of Animal Science, University of Agricultural Sciences, \\ Gregor Mendel-Strasse 33, A-1180 Vienna, Austria \\ ${ }^{\mathrm{b}}$ Department of Animal Science, University of Nebraska, Lincoln, NE 68583-0908, USA \\ ${ }^{\mathrm{c}}$ Department of Animal Science, Cornell University, Ithaca, NY 14853, USA \\ d Agricultural Research Service, USDA, Ithaca, NY 14853, USA \\ e Department of Microbiology, Cornell University, Ithaca, NY 14853, USA
}

Received 28 August 2001; received in revised form 13 May 2002; accepted 13 May 2002

\begin{abstract}
A short term feeding trial was conducted to assess effects of nitrogen $(\mathrm{N})$ supplementation on growing cattle and the ability of the Cornell Net Carbohydrate and Protein System (CNCPS) to predict responses. Four corn-based diets were used: (1) a 30\% ruminal N-deficient control diet; (2) a urea supplemented diet; (3) a urea + isolated soy protein (ISP) diet; and (4) a urea +ISP+blood meal (BM) diet. Four Holstein steers (average initial body weight of $251 \mathrm{~kg}$ ) were randomly assigned in a $4 \times 4$ Latin Square treatment design. Steers were fed $95 \%$ of ad libitum intake on an hourly basis, and $500 \mu \mathrm{g}$ of oestradiol- $17 \beta$ were administered twice daily. Average daily gain (ADG) increased $(P<0.05)$ when urea was added to the diet, but including urea + ISP was not better than the control or urea alone $(P>0.05)$. The urea + ISP + BM diet was better than the control or urea + ISP diets $(P<0.05)$, but it was not better than urea alone $(P>0.05)$. Addition of ISP or ISP $+\mathrm{BM}$ to the urea diet did not increase whole tract true digestibility of neutral detergent fibre, acid detergent fibre, or apparent digestibility of the dietary non-structural carbohydrate fraction $(P>0.05)$. The addition of urea, ISP or ISP + BM to the control diet caused an increase in N intake $(P<0.05)$, but faecal $\mathrm{N}$ did not increase $(P>0.05)$. Urinary $\mathrm{N}$ excretion increased 2.8 -fold compared to the control diet when urea, ISP or ISP + BM were added $(P<0.05)$, but there was no difference between these latter three treatments $(P>0.05)$. Urea, ISP and ISP + BM increased N retention $(P<0.05)$, and ISP $+\mathrm{BM}$ was higher than urea and ISP $(P<0.05)$. The numerical difference in $\mathrm{N}$ retention between urea and urea + ISP was not significant $(P>0.05)$. When urea, ISP or ISP + BM were added, plasma urea $\mathrm{N}$ increased $(P<0.05)$, but these three treatments had no effect on glucose, non-esterified fatty acids or insulin $(P>0.05)$. Results show that a ruminal $\mathrm{N}$-deficiency can have a negative impact on ADG, and this effect was consistent with predictions made by the CNCPS. Substitution of urea
\end{abstract}

\footnotetext{
* Corresponding author. Tel.: +43-1-47654x3285; fax: +43-1-47654x3254.

E-mail address: knaus@edv1.boku.ac.at (W.F. Knaus).
} 
by ISP did not cause an increase in ADG, indicating that ISP may not be as ruminally degradable as urea. Blood meal increased ADG, consistent with CNCPS predictions. Because ISP could have been a source of ruminally undegradable protein rather than ruminal peptides and amino acids, the peptide stimulation predictions of the CNCPS could not be evaluated.

(C) 2002 Elsevier Science B.V. All rights reserved.

Keywords: Steers; Nitrogen balance; Digestion; Urea; Peptides; Blood meal

\section{Introduction}

Microbial protein is an important amino acid (AA) source for cattle, but nitrogen (N) requirements for optimum growth of the mixed ruminal bacterial population have not been strictly defined (Carro and Miller, 1999). Most ruminal bacteria can utilise ammonia, but they often grow more efficiently when amino-N is provided (Hume, 1970). It has been demonstrated that growth of ruminal bacteria is stimulated by AA and peptides (Cotta and Russell, 1982; Cruz Soto et al., 1994). However, Hoover and Stokes (1991) showed that a combination of ammonia, peptides and amino acids allowed mixed ruminal bacteria to have the highest maximum growth rate.

The Cornell Net Carbohydrate and Protein System (CNCPS; Fox et al., 1992) uses rates of carbohydrate and protein degradation to estimate microbial growth in the rumen (Russell et al., 1992). The CNCPS classifies ruminal bacteria according to their ability to utilise carbohydrates and $\mathrm{N}$. In the CNCPS, fibre-digesting bacteria use only ammonia as an $\mathrm{N}$ source. However, those that ferment non-structural carbohydrates (NSC) use either ammonia or peptides, and they can produce ammonia from AA. Carro and Miller (1999) concluded that fibre-digesting ruminal micro-organisms needed peptides and amino acids to maximise growth rate and fibre digestion. However, Atasoglu et al. (2001) indicated that cellulolytic ruminal bacteria did not incorporate much amino-N into cell protein. Oh et al. (1999) questioned the assumption that amylolytic bacteria are stimulated to maximal growth by pre-formed peptides and AA.

We hypothesised that amino-N (peptides and pre-formed AA) would increase rate and efficiency of microbial protein synthesis, as long as adequate amounts and sources of carbohydrates were available. These increases would in turn improve the $\mathrm{N}$ balance of animals with high metabolisable protein (MP) requirements. Additionally, we hypothesised that an excess supply of ruminally undegradable protein (RUP) would not increase $\mathrm{N}$ retention. Cattle were fed a low crude protein (CP), corn-based control diet supplemented with urea, or urea + isolated soy protein (ISP), or urea + ISP + blood meal (BM). Growth and N balance data were compared to predictions given by the CNCPS 4.0.

\section{Materials and methods}

\subsection{Animals and diets}

Four Holstein steers weighing $220 \pm 6.1 \mathrm{~kg}$ were purchased from a commercial feedlot and transported to the Beef Unit of the Cornell University Animal Science Teaching and 
Research Center (Dryden, NY, USA). Anabolic implants were removed, and after 3 weeks the animals were brought to the Cornell University Large Animal Research and Teaching Unit in Ithaca, NY, USA.

Animals were fitted with halters and body-clipped within the first few hours of arrival. They were housed in four individual metabolism stalls in a monitor room under environmentally-controlled thermoneutral conditions $\left(20 \pm 2{ }^{\circ} \mathrm{C}, 16 \mathrm{~h}\right.$ light: $8 \mathrm{~h}$ dark $)$ and acclimated for 2 weeks before the onset of the study. The metabolism stalls were constructed of galvanised pipe ( $3.8 \mathrm{~cm}$ diameter) over rubber-padded concrete flooring with metal grates for faecal collections. Stall measurements were $2.3 \mathrm{~m}$ long $\times 1.1 \mathrm{~m}$ wide. The experiment was conducted under the approval and supervision of the Cornell University Institutional Animal Care and Use Committee.

Prior to ration formulation, stored mature mixed grass hay and cracked corn grain intended for use as dietary ingredients were chemically analysed for the parameters needed for input in the CNCPS model (Fox et al., 1992; Ainslie et al., 1993; Tedeschi et al., 2000) ration simulations. Analyses were conducted at the Northeast Dairy Herd Improvement Association (DHI) Forage Testing Laboratory (Dairy One Forage Lab Analytical Procedures $-11 / 01$; Ithaca, NY, USA). In this laboratory neutral detergent fibre (NDF) is assayed with sodium sulfite and alpha amylase and is expressed without residual ash.

The CNCPS model version 4.0 (Fox et al., 2000) was used to formulate a corn-based control diet of $70 \%$ cracked corn and $30 \%$ chopped low-protein mixed grass hay that would result in a predicted $30 \%$ ruminal $\mathrm{N}$-deficiency for $250 \mathrm{~kg}$ large-framed steers (Table 1). This dry mixed complete ration contained no protein supplement and no ionophore, and was predicted to accommodate a metabolisable energy (ME) and MP allowable average daily gain (ADG) of 1.4 and $0.8 \mathrm{~kg}$, respectively. For the control diet, the CNCPS model predicted a MP deficiency of $28 \%(-118 \mathrm{~g}$ per day) and a deficiency in ruminal peptides of $46 \%$ ( $-31 \mathrm{~g}$ per day) (Table 2 ). In order to determine the voluntary feed intake capacity for each animal, the control diet was offered on an ad libitum basis for 2 weeks prior to the onset of the first treatment period. Fresh feed was offered hourly via belttype feeders, and feed refusals were weighed daily at 09:00 h. Water was available continuously.

The CNCPS model was also used to estimate the amount of supplemental crystalline urea necessary to balance the control diet for rumen $\mathrm{N}$ requirements. The inclusion of urea at a level of $1.7 \%$ (DM basis) was predicted to result in a $100 \%$ balance of ruminal $\mathrm{N}$ requirements (urea diet), but left a deficiency in ruminal peptide balance of $46 \%(-31 \mathrm{~g}$ per day) (Table 2). A third diet (urea + ISP diet) was formulated to balance the rumen for $\mathrm{N}$ and peptides through the inclusion of $3.6 \%$ (DM basis) commercial isolated soy protein $\left(\mathrm{SUPRO}^{\circledR}\right.$ 500E, Protein Technologies, St. Louis, MO, USA). The urea and the urea + ISP diets were predicted to meet or exceed the MP requirements of the steers (i.e. 13 and $7 \mathrm{~g}$ per day in excess of requirement). The BM was added to the fourth diet at a level of $3.2 \%$ on a DM basis (urea + ISP + BM diet), to determine if this RUP would further enhance rate or efficiency of $\mathrm{N}$ retention. The basis for this treatment was established in a study by Knaus et al. (1998), in which RUP addition improved both parameters. The ring-dried BM originated from the same processing plant as that used in the previous experiment (Knaus et al., 1998). All four diets were mixed in batches sufficient for the entire experiment and were stored at room temperature. 
Table 1

Ingredients and chemical compositions of corn-based diets fed to steers

\begin{tabular}{|c|c|c|c|c|}
\hline & \multicolumn{4}{|l|}{$\operatorname{Diet}^{\mathrm{a}}$} \\
\hline & Control & Urea & Urea + ISP & Urea + ISP + BM \\
\hline \multicolumn{5}{|l|}{ Ingredient (\% of DM) } \\
\hline Cracked corn grain & 68.3 & 67.1 & 65.3 & 64.7 \\
\hline Chopped mixed grass hay & 29.2 & 28.7 & 28.0 & 26.8 \\
\hline Urea & 0 & 1.7 & 0.6 & 0.8 \\
\hline Isolated soy protein & 0 & 0 & 3.6 & 2.0 \\
\hline Blood meal (ring-dried) & 0 & 0 & 0 & 3.2 \\
\hline Limestone & 1.2 & 1.2 & 1.2 & 1.2 \\
\hline Mineral mix ${ }^{\mathrm{b}}$ & 1.2 & 1.2 & 1.2 & 1.2 \\
\hline Vitamin premix $^{\mathrm{c}}$ & 0.1 & 0.1 & 0.1 & 0.1 \\
\hline \multicolumn{5}{|l|}{ Chemical composition (\% of DM) } \\
\hline Organic matter & 95.3 & 96.0 & 95.3 & 95.2 \\
\hline Crude protein & 7.9 & 12.8 & 12.8 & 15.3 \\
\hline Soluble protein & 1.8 & 6.8 & 4.4 & 4.7 \\
\hline Neutral detergent fibre & 28.4 & 25.2 & 27.0 & 25.6 \\
\hline Acid detergent fibre & 14.9 & 15.0 & 16.1 & 14.8 \\
\hline Non-structural carbohydrates ${ }^{\mathrm{d}}$ & 56.6 & 55.3 & 53.3 & 51.1 \\
\hline Calcium & 0.75 & 0.60 & 0.71 & 0.91 \\
\hline Phosphorus & 0.40 & 0.39 & 0.40 & 0.45 \\
\hline Magnesium & 0.15 & 0.14 & 0.15 & 0.16 \\
\hline Potassium & 0.70 & 0.66 & 0.66 & 0.62 \\
\hline Sodium & 0.10 & 0.09 & 0.12 & 0.17 \\
\hline \multicolumn{5}{|l|}{ Net energy (Mcal kg-1 DM) } \\
\hline Maintenance & 1.70 & 1.92 & 1.83 & 1.83 \\
\hline Gain & 1.08 & 1.28 & 1.19 & 1.19 \\
\hline
\end{tabular}

${ }^{a}$ ISP, isolated soy protein; BM, blood meal.

${ }^{\mathrm{b}}$ Contained $98 \%$ sodium chloride, $0.4 \%$ zinc, $0.4 \%$ iron, $0.3 \%$ manganese, $0.2 \%$ copper, $0.02 \%$ selenium, $0.007 \%$ iodine and $0.007 \%$ cobalt.

${ }^{\mathrm{c}}$ Contained $5000 \mathrm{IU} \mathrm{kg}^{-1}$ of Vitamin A, $2000 \mathrm{IU} \mathrm{kg}^{-1}$ of Vitamin D and $100 \mathrm{IU} \mathrm{kg}^{-1}$ of Vitamin E.

${ }^{\mathrm{d}}$ Non-structural carbohydrates $(\%)=100-(\mathrm{CP}+\mathrm{NDF}+$ crude fat + ash $)$.

Steers were randomly assigned to treatment diets arranged in a $4 \times 4$ balanced Latin Square treatment design. The four specific treatments were: (1) control diet; (2) urea diet; (3) urea + ISP diet; and (4) urea + ISP + BM diet. Ingredients and chemical composition of the diets are shown in Table 1. No ionophore or other feed additives were used, to avoid interference with rumen microbial activity.

The daily feed amount offered was fixed at $95 \%$ of ad libitum intake of the control diet for each steer, as determined prior to the onset of the trial, and was maintained at that level throughout the experiment. This was done in order to avoid intake fluctuations, which would complicate $\mathrm{N}$ balance determination and comparisons with in vitro findings from continuous culture fermenters. Each treatment period was 14 days in length, with the first 7 days serving as an adaptation period to the treatment, and $\mathrm{N}$ balance collections were conducted from day 8 to day 14 . Feed refusals were measured daily, but amounts were negligible. Animals were weighed at the beginning of the study, every 14 days at $21: 00 \mathrm{~h}$, and 
Table 2

Selected predictions of the Cornell Net Carbohydrate and Protein System model version $4.0^{\mathrm{a}}$ for corn-based diets fed to $278 \mathrm{~kg}$ Holstein steers based on actual DM intake shown in Table 3

\begin{tabular}{|c|c|c|c|c|}
\hline & \multicolumn{4}{|l|}{$\operatorname{Diet}^{\mathrm{b}}$} \\
\hline & Control & Urea & Urea + ISP & Urea + ISP + BM \\
\hline Crude protein (\% of DM) & 8.1 & 12.7 & 12.7 & 14.6 \\
\hline Soluble protein $(\%$ of $\mathrm{CP})$ & 24 & 52 & 51 & 39 \\
\hline Ruminally degradable protein (\% of CP) & 63 & 77 & 75 & 68 \\
\hline Non-structural carbohydrates ${ }^{\mathrm{c}}(\%$ of DM) & 56 & 55 & 53 & 53 \\
\hline Metabolisable energy allowable gain (kg per day) & 1.23 & 1.29 & 1.38 & 1.39 \\
\hline Metabolisable protein allowable gain (kg per day) & 0.83 & 1.33 & 1.40 & 1.68 \\
\hline Metabolisable protein balance $^{\mathrm{d}}$ (g per day) & -118 & 13 & 7 & 83 \\
\hline Rumen nitrogen balance (g per day) & -38 & 2 & 1 & 5 \\
\hline Peptide balance (g per day) & -31 & -31 & -1 & 1 \\
\hline Metabolisable protein from bacteria (g per day) & 339 & 473 & 475 & 459 \\
\hline Metabolisable protein from RUP (g per day) & 158 & 156 & 172 & 266 \\
\hline
\end{tabular}

on the following morning at 09:00 $\mathrm{h}$, to monitor and estimate growth rate. To simulate effects of an oestrogenic implant, $500 \mu \mathrm{g}$ of oestradiol-17 $\beta$ was injected subcutaneously (s.c.) in the front shoulder twice daily, starting 2 weeks before initiation of treatments. The injection site was alternated between right and left shoulder after every injection. Oestradiol-17 $\beta$ administration was via injection to avoid the characteristic reducing rate-of-release pattern exhibited by oestrogenic implants.

\subsection{Sample collection and analysis}

Total faeces, urine, and feed refusals were collected at 09:00 h daily during the $\mathrm{N}$ balance collection periods. Continuous collection of the urine was accomplished using a rubber funnel and vacuum system harnessed to the ventral portion of the abdomen and connected to a plastic carboy. In order to avoid volatilisation of ammonia, urine acidity was reduced to $\mathrm{pH}<2$ by adding $200 \mathrm{ml}$ of $12 \mathrm{~N} \mathrm{H}_{2} \mathrm{SO}_{4}$ to the collection reservoir. Urine volume was recorded daily, and $10 \%$ aliquots, by volume, were collected and composited for each steer for all 7 days within a collection period. Subsamples of urine were stored at $-18{ }^{\circ} \mathrm{C}$.

Daily wet weight of faeces was measured for each individual steer and faeces were homogenised with $37 \%$ (v/v) formaldehyde solution $\left(0.25 \mathrm{ml} \mathrm{kg}^{-1}\right.$ wet faeces) to retard spoilage. Feed refusals and $10 \%$ aliquots of the faeces were dried in a forced-air oven at $65^{\circ} \mathrm{C}$ to a constant weight. Orts, feed, and faecal samples were ground separately to pass a $1 \mathrm{~mm}$ screen using a Wiley mill. Feed refusal samples and faecal samples were each composited during grinding for each animal within each collection period. 
Between 10:30 and 11:00 h on day 14 of each treatment, a venous blood sample was drawn from each steer with a syringe and immediately transferred to a heparinized tube. Samples were kept on ice until they were centrifuged at $0-4{ }^{\circ} \mathrm{C}$ and $3000 \times g$ for $20 \mathrm{~min}$. Plasma was harvested, aliquotted into storage tubes and immediately frozen at $-18^{\circ} \mathrm{C}$.

The chemical composition of feedstuffs, total diets, orts and faeces were determined at the Northeast Dairy Herd Improvement Association Forage Testing Laboratory (Dairy One Forage Lab Analytical Procedures - 11/01; Ithaca, NY, USA). In addition, N content of feed, feed refusals, faeces and urine were determined by macro Kjeldahl analysis (AOAC, 1990) of duplicate samples. Non-structural carbohydrate (NSC) content was calculated by difference ( $\mathrm{NSC}=\mathrm{DM}-\mathrm{CP}-$ neutral detergent fibre - crude fat - ash). Because metabolic CP contains $7 \% \mathrm{~N}$ (Van Soest, 1994), faecal N was multiplied by the factor 14 to express it as CP.

All blood plasma samples collected from each animal during each treatment period were assayed for glucose, urea N, non-esterified fatty acids (NEFA) and insulin concentrations. Plasma glucose concentrations were determined with the Sigma kit (Procedure \#510, Sigma, St. Louis, MO, USA) for colorimetric determination, using the method described by Raabo and Terkildsen (1960). Plasma urea N (PUN) was measured based on methods described by Fawcett and Scott (1960) and by Chaney and Marbach (1962), using the Sigma kit (Procedure \#640B, Sigma, St. Louis, MO, USA). Concentrations of NEFA in plasma were measured by a modification of an enzymatic colorimetric kit (NEFA-C, Cat. No. 990-75401, Wako Pure Chemical Industries, Dallas, TX, USA). Plasma insulin concentrations were determined by a double antibody RIA system (McGuire et al., 1995).

\subsection{Statistical analysis}

All statistical analyses were conducted using Model 1 of the Mixed Model Least-Squares and Maximum Likelihood Computer Program by Harvey (1990). Data were analysed as a completely randomised $4 \times 4$ Latin Square treatment design. The model sums of squares were partitioned into the main effects of animal, period and treatment. Differences between treatment means were analysed using the BONFERRONI-HOLM multiple comparison test procedure (Holm, 1979) when treatment effects were significant. All data are presented as least-squares means. Differences were considered to be statistically significant when $P<0.05$.

\section{Results}

\subsection{Composition of diets}

To evaluate the predictions made by the CNCPS, cattle were fed diets containing a 70:30 ratio of cracked corn grain and chopped mature mixed grass hay (Table 1). The CP content of this control diet was only $7.9 \%$. Addition of $1.7 \%$ crystalline urea increased the CP in the control diet by approximately $38 \%$. The urea and the urea + ISP diets were isonitrogenous. The addition of BM (3.2\% of diet DM) to the urea + ISP diet increased the CP content to $15.3 \%$. 


\subsection{CNCPS predictions}

The CNCPS model predicted a ruminal N-deficiency of $38 \mathrm{~g}$ per day and a peptide deficiency of $31 \mathrm{~g}$ per day for the control diet (Table 2). Addition of crystalline urea increased predicted flow of bacterial protein by $134 \mathrm{~g}$ per day, an increase of $40 \%$. Consequently, the predicted MP allowable ADG was increased by $60 \%(0.83-1.33 \mathrm{~kg}$ per day). The CNCPS indicated that the urea, urea + ISP and urea + ISP + BM diets had similar ME and MP allowable gains. Addition of BM had little effect on bacterial protein, but it increased RUP by $55 \%$.

\subsection{Feed intake and body weight gain}

Average ad libitum dry matter intake (DMI) of the control diet prior to the onset of the experiment was $6.9 \mathrm{~kg}$ per day. Average daily gain increased $(P<0.05)$ when urea was added to the diet (Table 3), but including urea + ISP was not better than the control or urea alone $(P>0.05)$. The urea + ISP + BM diet was better than the control or urea + ISP diets $(P<0.05)$, but it was not better than urea alone $(P>0.05)$.

\subsection{Total tract digestibility}

Whole tract apparent digestibility of $\mathrm{N}$ was improved by $45 \%(P<0.01)$ when urea was added to the control diet, and DM and organic matter $(\mathrm{OM})$ digestibility tended $(P=0.078)$ to improve. Addition of ISP or ISP $+\mathrm{BM}$ to the urea diet did not increase whole tract true digestibility of NDF, acid detergent fibre (ADF), or apparent digestibility of the dietary NSC fraction $(P>0.05)$.

\subsection{Nitrogen balance}

The addition of urea, ISP or ISP $+\mathrm{BM}$ to the control diet caused a significant increase in $\mathrm{N}$ intake $(P<0.05)$, but faecal $\mathrm{N}$ did not increase $(P>0.05)$. Urinary $\mathrm{N}$ excretion increased 2.8-fold as compared to the control diet when urea, ISP or ISP + BM were added $(P<0.05)$, but there was no difference between these latter three treatments $(P>0.05)$. Addition of urea, ISP and ISP + BM increased N retention $(P<0.05)$, whereas, the increase observed with ISP + BM was greater than that with urea and ISP $(P<0.05)$. The difference in $\mathrm{N}$ retention between the urea and urea + ISP diets was not statistically significant $(P>0.05)$. The efficiency of $\mathrm{N}$ utilisation, calculated as $\mathrm{N}$ retained divided by $\mathrm{N}$ intake, was markedly improved $(P<0.05)$ for the urea $+\mathrm{ISP}+\mathrm{BM}$ diet as compared to the control diet.

\subsection{Blood variables}

By design, the control diet was markedly CP-deficient and PUN concentrations were low (2.2 $\mathrm{mg} \mathrm{dl}^{-1}$, Table 4). When urea, ISP or ISP+BM were added, PUN increased $(P<0.05)$, but these three treatments had no effect on glucose, NEFA or insulin $(P>0.05)$. 
Table 3

Effects of dietary urea, isolated soy protein and blood meal on total tract digestibility and $\mathrm{N}$ metabolism

\begin{tabular}{|c|c|c|c|c|c|c|}
\hline & \multicolumn{4}{|l|}{ Diet $^{\mathrm{a}}$} & \multirow[t]{2}{*}{ R.S.D. ${ }^{b}$} & \multirow[t]{2}{*}{$P$} \\
\hline & Control & Urea & Urea + ISP & Urea + ISP + BM & & \\
\hline Dry matter intake (kg per day) & $6.47 \mathrm{c}$ & $6.49 \mathrm{c}$ & $6.56 \mathrm{~d}$ & $6.56 \mathrm{~d}$ & $<0.01$ & $<0.001$ \\
\hline Dry matter intake $\left[\mathrm{kg}(100 \mathrm{~kg})^{-1}\right.$ initial body weight] & $2.58 \mathrm{c}$ & $2.59 \mathrm{c}$ & $2.62 \mathrm{~d}$ & $2.62 \mathrm{~d}$ & $<0.01$ & $<0.001$ \\
\hline Average daily gain (g per day) & $624 \mathrm{c}$ & $1094 \mathrm{~d}, \mathrm{e}$ & $850 \mathrm{c}, \mathrm{d}$ & $1272 \mathrm{e}$ & 156 & 0.005 \\
\hline \multicolumn{7}{|l|}{ Total tract apparent digestion $\left(\mathrm{g} \mathrm{kg}^{-1}\right)$} \\
\hline Dry matter & 590 & 660 & 656 & 659 & 29 & $0.033^{\mathrm{c}}$ \\
\hline Organic matter & 595 & 667 & 663 & 664 & 29 & $0.035^{\circ}$ \\
\hline Nitrogen & $443 \mathrm{c}$ & $640 \mathrm{~d}, \mathrm{e}$ & $624 \mathrm{~d}$ & $675 \mathrm{e}$ & 18 & $<0.001$ \\
\hline Acid detergent fibre & 322 & 390 & 457 & 458 & 76 & 0.124 \\
\hline Neutral detergent fibre & 398 & 450 & 497 & 480 & 52 & 0.130 \\
\hline Non-structural carbohydrates ${ }^{\mathrm{d}}$ & 813 & 875 & 872 & 877 & 34 & 0.101 \\
\hline \multicolumn{7}{|l|}{ Nitrogen balance } \\
\hline Intake ( $\mathrm{g}$ per day) & $81.8 \mathrm{c}$ & $133.0 \mathrm{~d}$ & $134.4 \mathrm{~d}$ & $160.5 \mathrm{e}$ & 0.9 & $<0.001$ \\
\hline Faecal (g per day) & 45.6 & 47.8 & 50.5 & 52.2 & 2.6 & $0.045^{\mathrm{c}}$ \\
\hline Urinary ( $\mathrm{g}$ per day) & $16.7 \mathrm{c}$ & $47.2 \mathrm{~d}$ & $41.5 \mathrm{~d}$ & $50.2 \mathrm{~d}$ & 6.8 & 0.002 \\
\hline Retention ( $\mathrm{g}$ per day) & $19.5 \mathrm{c}$ & $37.9 \mathrm{~d}$ & $42.4 \mathrm{~d}$ & $58.1 \mathrm{e}$ & 5.3 & $<0.001$ \\
\hline Retention ( $\%$ of $\mathrm{N}$ intake) & $23.8 \mathrm{c}$ & $28.5 \mathrm{c}, \mathrm{d}$ & $31.5 \mathrm{c}, \mathrm{d}$ & $36.2 \mathrm{~d}$ & 4.1 & 0.026 \\
\hline
\end{tabular}

Means within a row with different letters (c, d, e) differ $(P<0.05)$.

${ }^{\text {a }}$ ISP, isolated soy protein; BM, blood meal.

${ }^{\mathrm{b}}$ R.S.D., residual standard deviation.

${ }^{c}$ Pairwise comparison using BONFERRONI-HOLM test procedure resulted in non-significant $(P<0.05)$ difference.

${ }^{\mathrm{d}}$ Non-structural carbohydrates $(\%)=100-(\mathrm{CP}+\mathrm{NDF}+$ crude fat + ash $)$. 
Table 4

Plasma urea $\mathrm{N}$, glucose, non-esterified fatty acids and insulin concentrations

\begin{tabular}{|c|c|c|c|c|c|c|}
\hline & \multicolumn{4}{|l|}{$\operatorname{Diet}^{\mathrm{a}}$} & \multirow[t]{2}{*}{ R.S.D. ${ }^{b}$} & \multirow[t]{2}{*}{$P$} \\
\hline & Control & Urea & Urea + ISP & $\mathrm{Urea}+\mathrm{ISP}+\mathrm{BM}$ & & \\
\hline Plasma urea $\mathrm{N}\left(\mathrm{mg} \mathrm{dl}^{-1}\right)$ & $2.2 \mathrm{c}$ & $8.7 \mathrm{~d}$ & $7.0 \mathrm{~d}$ & $7.5 \mathrm{~d}$ & 1.4 & 0.003 \\
\hline Glucose $\left(\mathrm{mg} \mathrm{dl}^{-1}\right)$ & 103.3 & 102.9 & 104.2 & 113.8 & 7.5 & 0.233 \\
\hline Non-esterified fatty acids $\left(\mu \mathrm{mol}^{-1}\right)$ & 114.1 & 125.8 & 99.5 & 122.3 & 25.3 & 0.511 \\
\hline Insulin $\left(\mathrm{ng} \mathrm{ml}^{-1}\right)$ & 0.70 & 0.65 & 0.70 & 0.85 & 0.35 & 0.870 \\
\hline
\end{tabular}

Means within a row with different letters $(\mathrm{c}, \mathrm{d})$ differ $(P<0.05)$.

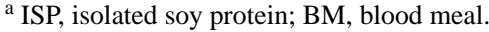

${ }^{\mathrm{b}}$ R.S.D., residual standard deviation.

\section{Discussion}

Previous work has indicated that a ruminal N limitation can reduce DMI (NRC, 1985, 1987; Van Soest, 1994). We restricted DMI to $95 \%$ of ad libitum, but the DMI of the control and urea diets was lower than that of the urea + ISP or urea + ISP + BM diets $(P<0.05)$. These differences are due to the slightly higher DM content of the urea + ISP and the urea + ISP + BM diets. The DMI values in this present study were similar to those observed in a recent study with steers (Knaus et al., 2001).

Growth performance observed in the present $\mathrm{N}$ balance study must be interpreted with care due to the length of treatment periods and possible differences in bladder and/or gut fill. Chemical analyses indicated that the solubility of CP was only 34 and $31 \%$ for the urea + ISP and the urea + ISP + BM diets, respectively. According to the producer's specifications, the nitrogen solubility index (NSI; AOCS, 1997) of SUPRO ${ }^{\circledR} 500 \mathrm{E}$ is typically $90 \%$. The ISP was stored at room temperature and used within 3 months of arrival. We had hypothesised that the ISP would alleviate the ruminal N-deficiency to a greater extent than urea, because in theory the ISP would have increased microbial protein synthesis via peptide stimulation.

Argyle and Baldwin (1989) reported that the growth of mixed ruminal bacteria was a linear function of fermented carbohydrates, and growth was greatly stimulated by the provision of peptides and AA. When Milton et al. (1997b) fed a dry-rolled corn-based (>73\% DM basis) diet supplemented with urea to growing cattle, the addition of soybean meal (SBM) or cottonseed meal increased body weight gain, and similar effects were noted by Braman et al. (1973) and Sindt et al. (1994). In our study, the ADG of the urea + ISP diet was not better than that of the urea diet $(P>0.05)$, but it should be noted that we replaced urea with ISP. This result indicates that the ISP may not have been as ruminally degradable as urea, or alternatively, that the peptide requirement had already been met. Further work is needed to clarify this effect. Growth rates observed with the urea and the urea + ISP + BM diets are similar to results reported by Knaus et al. (2001).

Ruminal N limitation can depress fibre digestibility (Russell et al., 1992; Tedeschi et al., 2000), and this effect can be greater if branched-chain volatile fatty acids are not available (Russell, 1984). However, Milton et al. (1997a) did not observe an increase in total tract digestion of ADF when dry-rolled corn-based diets were supplemented with urea. Carro and Miller (1999) reported that ADF and cellulose degradability of a diet consisting of 
NDF, obtained from grass hay and sugarbeet pulp in a semicontinuous culture system (RUSITEC), were greater $(P \leq 0.05)$ after the addition of commercial ISP SUPRO ${ }^{\circledR} 500 \mathrm{E}$ than after an enzyme hydrolysate of soybean protein treatment. We did not observe an increase in NDF or ADF digestion in our trial $(P>0.05)$. The CNCPS assumes that starch digestibility is not affected by $\mathrm{N}$ availability (Tedeschi et al., 2000), but Milton et al. (1997b) observed a 5\% $(P<0.10)$ increase in total tract starch digestion when steers were fed rolled corn-based diets supplemented with SBM as compared to urea. Our study indicated that NSC digestibility was unaffected by any of the treatments $(P>0.05)$. These results are in accordance with observations made by Martín-Orue et al. (2000). Effective rumen degradable protein in high-grain diets enhanced microbial protein supply to the host animal without any considerable increase in digestion of OM and starch.

Ruminally undegradable protein can increase animal performance if the supply of bacterial protein from the rumen is insufficient, but by-product proteins can cause a negative peptide balance for ruminal bacteria even if bacterial $\mathrm{N}$ balance and MP balance remain positive (Knaus et al., 1998, 2001). Our results indicate that BM increased ADG. Total N intake of the urea + ISP+BM diet was $161 \mathrm{~g}$ per day and $\mathrm{N}$ retention was $58.1 \mathrm{~g}$ per day, a value similar to previously reported data (Knaus et al., 2001). In two studies in which casein was abomasally infused into Holstein steers, $\mathrm{N}$ retentions were 58 (Moloney et al., 1998) and $64 \mathrm{~g}$ per day (Robinson, 1998). Houseknecht et al. (1992) reported a $25 \%$ efficiency of $\mathrm{N}$ retention in steers that were fed a 66:34 concentrate-hay diet and received abomasal infusions of casein.

Addition of urea caused an increase in PUN $(P<0.05)$, but the inclusion of ISP or BM resulted in no further increase $(P>0.05)$. This indicates that these other $\mathrm{N}$ sources did not cause ammonia accumulation in the rumen, and were either incorporated into microbial-N matter or passed to the lower gut as RUP. The mean PUN concentration observed with the urea diet was similar to concentrations of $9.5 \mathrm{mg} \mathrm{dl}^{-1}$ observed by Knaus et al. (2001). If RUP is very high, PUN can increase (Robinson, 1998; Houseknecht et al., 1992; Moloney et al., 1998; Wessels and Titgemeyer, 1997), but BM did not cause a higher PUN than urea. These latter results indicated that our animals did not have excess RUP.

When McGuire et al. (1992) increased the dietary CP of lactating dairy cows, plasma glucose and NEFA concentrations did not increase, but plasma insulin concentrations were higher. Higher plasma insulin concentrations were observed after abomasal casein infusion in steers (Guerino et al., 1991; Ragland-Gray et al., 1997; Robinson, 1998) and lambs (Beermann et al., 1991). However, we did not observe an increase in glucose, NEFA or insulin $(P>0.05)$.

\section{Conclusions}

Results show that a ruminal N-deficiency can have a negative impact on ADG, and this effect was consistent with predictions made by the CNCPS. Substitution of urea with ISP did not cause an increase in ADG, and this result indicates that ISP may not be as ruminally degradable as urea. Since ISP could have been a source of RUP rather than ruminal peptides and amino acids, the peptide stimulation predicted by the CNCPS could not be evaluated. Addition of BM resulted in an increased ADG and this was consistent with predictions made by the CNCPS. 


\section{Acknowledgements}

The authors express their gratitude to the Austrian Science Foundation (FWF) for financial support of this research in the form of the Erwin Schroedinger Scholarship for W.F. Knaus. Gratitude is also expressed to Deborah Ketchen, Bill English, Susanne Pelton and Lisa Furman for skilled technical assistance, Joanne Parsons for her practical support and Kathleen Knaus for editing assistance. The authors also wish to extend their grateful thanks to Protein Technologies International, St. Louis, MO, USA, for the donation of isolated soy protein SUPRO ${ }^{\circledR} 500 \mathrm{E}$ and to Taylor By-Products Inc., Wyalusing, PA, USA, for providing the blood meal.

\section{References}

Ainslie, S.J., Fox, D.G., Perry, T.C., Ketchen, D.J., Barry, M.C., 1993. Predicting amino acid adequacy of diets fed to Holstein steers. J. Anim. Sci. 71, 1312-1319.

AOAC, 1990. Official Methods of Analysis, 15th ed. Association of Official Analytical Chemists, Arlington, VA, USA.

AOCS, 1997. Official Method Ba 11-65. The American Oil Chemists' Society, Champaign, IL, USA.

Argyle, J.L., Baldwin, R.L., 1989. Effects of amino acids and peptides on rumen microbial growth yields. J. Dairy Sci. 72, 2017-2027.

Atasoglu, C., Newbold, C.J., Wallace, R.J., 2001. Incorporation of [15N] ammonia by the cellulolytic ruminal bacteria Fibrobacter succinogenes BL2, Ruminococcus albus SY3, and Ruminococcus flavefaciens 17. Appl. Environ. Microbiol. 67, 2819-2822.

Beermann, D.H., Robinson, T.F., Byrem, T.M., Hogue, D.E., Bell, A.W., McLaughlin, C.L., 1991. Abomasal casein infusion and exogenous somatotropin enhance nitrogen utilisation by growing lambs. J. Nutr. 121, 2020-2028.

Braman, W.L., Hatfield, E.E., Owens, F.N., Lewis, J.M., 1973. Protein concentration and sources for finishing ruminants fed high-concentrate diets. J. Anim. Sci. 36, 782-787.

Carro, M.D., Miller, E.L., 1999. Effect of supplementing a fibre basal diet with different nitrogen forms on ruminal fermentation and microbial growth in an in vitro semi-continuous culture system (RUSITEC). Br. J. Nutr. 82, $149-157$.

Chaney, A.L., Marbach, E.P., 1962. Modified reagent for determination of urea and ammonia. Clin. Chem. 8, $130-132$.

Cotta, M.A., Russell, J.B., 1982. Effect of peptides and amino acids on efficiency of rumen bacterial protein synthesis in continuous culture. J. Dairy Sci. 65, 226-234.

Cruz Soto, R., Muhammed Samirah, A., Newbold, C.J., Steward, C.S., Wallace, R.J., 1994. Influence of peptides, amino acids and urea on microbial activity in the rumen of sheep receiving grass hay and on the growth of rumen bacteria in vitro. Anim. Feed Sci. Technol. 49, 151-161.

Fawcett, J.K., Scott, J.E., 1960. A rapid and precise method for the determination of urea. J. Clin. Pathol. 13, $156-159$.

Fox, D.G., Sniffen, C.J., O’Connor, J.D., Russell, J.B., Van Soest, P.J., 1992. A Net Carbohydrate and Protein System for evaluating cattle diets: Part III. Cattle requirements and diet adequacy. J. Anim. Sci. 70, 3578-3596.

Fox, D.G., Tylutki, T.P., Van Amburgh, M.E., Chase, L.E., Pell, A.N., Overton, T.R., Tedeschi, L.O., Rasmussen, C.N., Durbal, V.M., 2000. The Net Carbohydrate and Protein System for Evaluating Herd Nutrition and Nutrient Excretion: Model Documentation. Mimeo No. 213, Department of Animal Science, Cornell University, Ithaca, NY, USA.

Guerino, F., Huntington, G.B., Erdman, R.A., Elsasser, T.H., Reynolds, C.K., 1991. The effects of abomasal casein infusions in growing beef steers on portal and hepatic flux of pancreatic hormones and arterial concentrations of somatomedin-C. J. Anim. Sci. 69, 379-386.

Harvey, W.R., 1990. User's Guide to LSMLMW. Mixed Model Least-Squares and Maximum Likelihood Computer Program. Polycopy Ohio State University, Columbus, OH, USA. 
Holm, S., 1979. A simple sequentially rejective multiple test procedure. Scand. J. Stat. 6, 65.

Hoover, W.H., Stokes, S.R., 1991. Balancing carbohydrates and proteins for optimum rumen microbial yield. J. Dairy Sci. 74, 3630-3644.

Houseknecht, K.L., Bauman, D.E., Fox, D.G., Smith, D.F., 1992. Abomasal infusion of casein enhances nitrogen retention in somatotropin-treated steers. J. Nutr. 122, 1717-1725.

Hume, I.D., 1970. Synthesis of microbial protein in the rumen. Part III. The effect of dietary protein. Aust. J. Agric. Res. 21, 305-314.

Knaus, W.F., Beermann, D.H., Robinson, T.F., Fox, D.G., Finnerty, K.D., 1998. Effects of a dietary mixture of meat and bone meal, feather meal, blood meal, and fish meal on nitrogen utilisation in finishing Holstein steers. J. Anim. Sci. 76, 1481-1487.

Knaus, W.F., Beermann, D.H., Guiroy, P.J., Boehm, M.L., Fox, D.G., 2001. Optimization of rate and efficiency of dietary nitrogen utilisation through the use of animal by-products and/or urea and their effects on nutrient digestion in Holstein steers. J. Anim. Sci. 79, 753-760.

Martín-Orue, S.M., Balcells, J., Vicente, F., Castrillo, C., 2000. Influence of dietary rumen-degradable protein supply on rumen characteristics and carbohydrate fermentation in beef cattle offered high-grain diets. Anim. Feed Sci. Technol. 88, 59-77.

McGuire, M.A., Bauman, D.E., Miller, M.A., Hartnell, G.F., 1992. Response of somatomedins (IGF-I and IGF-II) in lactating cows to variations in dietary energy and protein and treatment with recombinant $n$-methionyl bovine somatotropin. J. Nutr. 122, 128-136.

McGuire, M.A., Bauman, D.E., Dwyer, D.A., Cohick, W.S., 1995. Nutritional modulation of the somatotropin/ insulin-like growth factor system: response to feed deprivation in lactating cows. J. Nutr. 125, 493-502.

Milton, C.T., Brandt Jr., R.T., Titgemeyer, E.C., 1997a. Urea in dry-rolled corn diets: finishing steer performance, nutrient digestion, and microbial protein production. J. Anim. Sci. 75, 1415-1424.

Milton, C.T., Brandt Jr., R.T., Titgemeyer, E.C., 1997b. Effects of dietary nitrogen source and concentration in high-grain diets on finishing steer performance and nutrient digestion. J. Anim. Sci. 75, 2813-2823.

Moloney, A.P., Beermann, D.H., Gerrard, D., Robinson, T.F., Finnerty, K.D., 1998. Temporal change in skeletal muscle IGF-1 mRNA abundance and nitrogen metabolism responses to abomasal casein infusion in steers. J. Anim. Sci. 76, 1380-1388.

National Research Council (NRC), 1985. Ruminant Nitrogen Usage. National Academy Press, Washington, DC, USA.

National Research Council (NRC), 1987. Predicting Feed Intake of Food Producing Animals. National Academy Press, Washington, DC, USA.

Oh, Y.-G., Kim, K.H., Kim, J.-H., Choung, J.-J., Chamberlain, D.G., 1999. The effect of the form of nitrogen in the diet on ruminal fermentation and the yield of microbial protein in sheep consuming diets of grass silage supplemented with starch or sucrose. Anim. Feed Sci. Technol. 78, 227-237.

Raabo, E., Terkildsen, T.C., 1960. On the enzymatic determination of blood glucose. Scand. J. Clin. Lab. Invest. 12, 402-407.

Ragland-Gray, K.K., Amos, H.E., McCann, M.A., Williams, C.C., Sartin, J.L., Barb, C.R., Kautz, F.M., 1997. Nitrogen metabolism and hormonal responses of steers fed wheat silage and infused with amino acids or casein. J. Anim. Sci. 75, 3038-3045.

Robinson, T.F., 1998. Effect of undegradable intake protein on amino acid absorption and utilisation by the growing steer. Ph.D. dissertation, Cornell University, Ithaca, NY, USA.

Russell, J.B., 1984. Limits to the manipulation of rumen fermentation. In: Proceedings of the Conference on Cornell Nutrition. Syracuse, NY, USA, pp. 87-94.

Russell, J.B., O’Connor, J.D., Fox, D.G., Van Soest, P.J., Sniffen, C.J., 1992. A Net Carbohydrate and Protein System for evaluating cattle diets. Part I. Ruminal fermentation. J. Anim. Sci. 70, 3551-3561.

Sindt, M.H., Stock, R.A., Klopfenstein, T.J., 1994. Urea vs. urea and escape protein for finishing calves and yearlings. Anim. Feed Sci. Technol. 49, 103-117.

Tedeschi, L.O., Fox, D.G., Russell, J.B., 2000. Accounting for the effects of a ruminal nitrogen deficiency within the structure of the Cornell Net Carbohydrate and Protein System. J. Anim. Sci. 78, 1648-1658.

Van Soest, P.J., 1994. Nutritional Ecology of the Ruminant, 2nd ed. Cornell University Press, Ithaca, NY, USA (Chapters 18 and 21).

Wessels, R.H., Titgemeyer, E.C., 1997. Protein requirements of growing steers limit-fed corn-based diets. J. Anim. Sci. 75, 3278-3286. 